\title{
HUBUNGAN ANTARA KECERDASAN BAHASA DAN SIKAP SOSIAL SISWA KELAS V SD NEGERI MEKARSARI II KABUPATEN TANGERANG
}

\author{
Nur Latifah ${ }^{1}$, Mawardi ${ }^{2}$ \\ Universitas Muhammadiyah Tangerang \\ Nurlatifah1v4@gmail.com
}

\begin{abstract}
Abstrak
Tujuan penelitian ini adalah untuk mengetahui apakah hubungan kecerdasan bahasa dapat mempengaruhi sikap sosial siswa kelas V di SD Negeri Mekarsari II Kabupaten Tangerang. Penelitian ini adalah penelitian survei. Teknik pengambilan sampel penelitian ini menggunakan Sampling Purposive yaitu seluruh siswa kelas V yang berjumlah 144 siswa dan sampel dalam penelitian ini di kelas VC yang berjumlah 46 siswa. Hasil penelitian ini menunjukkan bahwa adanya hubungan positif dan signifikan antara Kecerdasan bahasa (X) dengan Sikap Sosial (Y), korelasi yang didapat sebesar 0,524 dengan persamaan regresi $\mathrm{Y}=54,11+0,50 \mathrm{X}$ dan koefisien determinasi sebesar 0,2745 yang berarti bahwa kecerdasan bahasa mempunyai kontribusi $27,45 \%$ terhadap sikap sosial siswa.
\end{abstract}

Kata kunci : Kecerdasan Bahasa, Sikap Sosial.

\section{A. Pendahuluan}

Manusia adalah makhluk sosial yang berbeda dengan makhluk yang lainnya. Manusia butuh interaksi dengan manusia yang lainnya. Oleh karena itu bahasa sangat penting bagi kehidupan manusia sebagai media berinteraksi dengang tujuan untuk menyampaikan gagasan dan pesan. Selaras dengan pendapat Kurniawan (2013:1) "bahasa digunakan oleh manusia sebagai media untuk menyampaikan informasi, pikiran dan perasaan kepada orang lain". Maka dengan adanya bahasa manusia dengan mudah berinteraksi dengan sesama.

Di dalam menyampaikan gagasan dibutuhkan sikap (atitude). Sikap berperan sebagai warna atau corak pada perilaku seseorang. Seseorang dapat memahami sebuah gagasan melalui pesan dan sikap yang ditunjukan oleh penutur. Sikap yang ditunjukkan 
oleh seseorang terbentuk sesuai dengan tuturannya.Sikap (attitude) mempunyai peran besar sebab sikap yang sudah terbentuk pada diri manusia turut membentuk tingkah lakunya dalam mengahadapi suatu objek.

Hasil observasi yang dilakukan oleh peneliti dalam pembelajaran, siswa yang diberikan tugas diskusi terlihat tidak produktif untuk berdiskusi, beberapa anak diam dan melamun atau bermain sendiri. Selain itu, sifat pemalu dan takut menjadi momok para siswa ketika melakukan diskusi. Mereka takut salah dan malu apabila pendapatnya kurang bagus. Kegiatan setelah observasi yaitu peneliti melakukan wawancara terhadap guru. Umumnya siswa memiliki tingkat sikap yang berbeda-beda, ada siswa yang pemarah, ada siswa yang pendiam, ada siswa yang hiperaktif, ada siswa yang pemalu dan sebagainya. Siswa juga memiliki sikap sosial yang berbeda, rata-rata siswa masih rendah dalam hal bersosial dikarenakan rasa individual yang sangat tinggi. Ketika persentasi pun masih banyak siswa yang sulit dalam mengungkapkan pendapatnya.

Setiap kelas memiliki siswa dengan keaktifan sosial dan kepekaan terhadap teman, guru, dan lingkungan sekolah yang berbeda-beda. Seharusnya siswa yang memiliki kecerdasan sikap yang tinggi mampu mengontrol diri, beradaptasi, berinteraksi, dan berempati kepada orang lain sehingga akan menunjukan sikap sosial yang baik saat berhubungan dengan teman atau guru di lingkungan sekolah. Berdasarkan latar belakang diatas peneliti membahas tentang sikap sosial yang kurang baik dan kurangnya siswa dalam mengelola kecerdasan sikapnya maka menjadikan dua variabel untuk diteliti. Maka, penelitian ini bertujuan untuk mengetahui apakah ada hubungan antara kecerdasan bahasa dengan sikap sosial siswa kelas V di SD Negeri Mekarsari II Kabupaten Tangerang.

\section{B. Kajian Pustaka}

Sikap yang dianut oleh banyak orang di sebut sikap sosial, sedangkan yang dianut hanya oleh satu orang tertentu saja yang disebut sikap sosial. Menurut Ahmadi (2007) sikap sosial dinyatakan tidak oleh seorang saja tetapi diperhatikan oleh orang-orang sekelompoknya. Objeknya adalah objek sosial (objeknya banyak dalam kelompok) dan 
dinyatakan berulang-ulang. Misalnya, sikap berkabung seluruh anggota kelompok karena meninggalnya seorang pahlawannya (h. 152).

Setiap orang bersikap dan bertingkah laku sesuai dengan perkembangan masingmasing individu tersebut. Dengan demikian, setiap orang harus mampu berinteraksi dan memiliki kepedulian terhadap orang lain. Adapun bentuk-bentuk sikap sosial menurut (Arifin, 2015, h. 131-133) dibedakan menjadi dua, yaitu sebagai berikut :

1) Sikap positif

a) Aspek kerja sama. Kerjasama merupakan suatu hubungan saling membantu dari tujuan.

b) Aspek solidaritas. Solidaritas merupakan salah satu bentuk sikap sosial yang dapat dilakukan seseorang dalam melihat ataupun memerhatikan orang lain, terutama seseorang yang mengalami suatu masalah.

c) Aspek tenggang rasa. Sikap tenggang rasa dapat dilihat dari adanya saling menghargai satu sama lain, menghindari sikap masa bodoh, tidak mengganggu orang lain, selalu menjaga perasaan orang lain, dalam bertutur kata tidak menyinggung perasaan orang lain, selalu menjaga perasaan orang lain dalam pergaulan, dan sebagainya.

2) Sikap negatif

a) Egoisme, yaitu bentuk sikap seseorang yang merasa dirinya paling unggul dalam segalanya dan tidak ada orang atau benda apapun yang mampu menjadi pesaingnya.

b) Prasangka sosial adalah sikap negatif yang diperlihatkan oleh individu atau kelompok terhadap individu lain atau kelompok lain. Dengan demikian, prasangka sosial merupakan sikap negetif yang ditunjukkan oleh individu terhadap individu atau kelompok lain.

c) Rasisme, yaitu sikap yang didasarkan pada kepercayaan bahwa suatu ciri yang dapat diamati dan dianggap diwarisi, seperti warna kulit merupakan tanda prihal inferioritas yang membenarkan perlakuan diskriminasi terhadap orang-orang yang mempunyai ciri-ciri tersebut.

d) Rasialisme, yaitu penerapan sikap diskriminasi terhadap kelompok ras lain. Misalnya, diskriminasi ras yang pernah terjadi di Afrika Selatan. 
e) Stereotip, yaitu citra kaku mengenai suatu ras atau budaya yang dianut tanpa memerhatikan kebenaran citra tersebut. Misalnya, stereotip masyarakat jawa adalah lemah lembut dan lamban dalam melakukan sesuatu. Stereotip tersebut tidak selalu benar karena tidak semua orang jawa memiliki sifat tersebut.

Sebuah kecerdasan bahasa bersifat universal dan dapat dimiliki setiap orang namun kecerdasan bahasa dipengaruhi oleh sikap seseorang. Sikap yang baik maka akan ditunjukkan dalam bertutur kata yang baik. Kecerdasan bahasa ditunjukkan oleh pengolahan bunyi, struktur kata, penyampaian makna, dan pengolahan kalimat. Kecerdasan bahasa dibiasanya dapat dilihat dalm kegiatan diskusi, rapat, presentasi maupun kegiatan keterampilan bahasa yang lainnya misalnya menulis, membaca, berbicara dan menyimak. Perkembangan bahasa terkait dengan perkembangan kemampuan anak dalam menggunakan kode-kode bahasa dalam mengungkapkan perasaan dan pikirannya (kurniawan, 2016:38-39).

\section{Metodologi Penelitian}

Penelitian ini menggunakan metode kuantitatif dengan menggunakan survey yang dianalisis secara deskriptif, yaitu memberi gambaran secermat mungkin mengenai dua variabel yang dihubungkan yakni variabel kecerdasan bahasa $(\mathrm{X})$ dengan variabel sikap sosial (Y). populasi dalam penelitian ini adalah seluruh siswa kelas $\mathrm{V}$ yang berjumlah 144 orang di SDN Mekarsari II Kabupaten Tangerang. Teknik pengambilan sampel pada penelitian ini menggunakan Sampling Purposive (penentuan sampel dengan pertimbangan tertentu.) adalah seluruh siswa kelas V yang berjumlah 144 siswa dan sampel dalam penelitian ini di kelas VC yang berjumlah 46 siswa.

Penelitian ini, pengumpulan data menggunakan metode observasi, wawancara dan angket. Peneliti melakukan observasi pada saat awal penelitian untuk mengetahui permasalahan dan mengetahui kondisi awal data. Setelah itu dilakukan wawancara yaitu saat observasi awal, peneliti melakukan interview/ wawancara kepada guru dan siswa untuk mengetahui permasalahan-permasalahan yang ada dan beberapa data pendukung. Angket yang digunakan dalam penelitian ini yaitu angket tertutup, pertanyaan atau 
pernyataan-pernyataan telah memiliki alternative jawaban (option) yang tinggal dipilih oleh responden.

Setelah data yang diperlukan terkumpul dan diolah, dan dilakukan analisis untuk mengetahui ada tidaknya hubungan dari kedua variabel tersebut sehingga dapat diperoleh suatu kesimpulan untuk menganalisa hubungan antara gejala interval, penulis menggunakan olah data statistik berupa : Statistik Deskriptif, yaitu untuk menyajikan data secara tunggal dari masing-masing variabel seperti tabel distribusi frekuensi, histogram, polygon, ogive, mean, median, modus, standar deviasi, dan lain sebagainya.

\section{Pembahasan Penelitian}

Sikap bukan dibawa sejak lahir, tetapi dipelajari dan dibentuk berdasarkan pengalaman sepanjang hayatnya. Pembentukan sikap merupakan hasil interaksi individu dengan lingkungannya. Pembentukan sikap seseorang adalah perpaduan faktor internal dengan faktor eksternal. Faktor internal sangat mempengaruhi sikap sosial siswa yaitu faktor yang ada di setiap individu. Sedangkan faktor eksternal yaitu faktor yang ada di sekitar individu. Kecerdasan tumbuh dan berkembang dipengaruhi juga oleh perkembangan sikap. Siswa yang memiliki sikap yang baik maka dapat menumbuhkan kecerdasan bahasa.

Siswa dengan sikap baik dan kecerdasan bahasa yang tinggi cenderung berfikir dahulu sebelum bertutur maupun dalam mengambil suatu tindakan dan juga menunjukkan sikap sosial yang baik terhadap teman, guru dan lingkungan. Namun siswa dengan kecerdasan sikap dan kecerdasan bahasa yang rendah, cenderung mengalami kesulitan untuk bertutur kata dan dalam mengambil suatu tindakan dan juga menunjukkan sikap sosial yang buruk terhadap teman, guru, dan lingkungannya.

Hal ini juga didukung oleh penelitian sebelumnya yang menunjukan bahwa kecerdasan bahasa dan sikap yang tinggi akan membuat siswa memiliki semangat yang tinggi dalam belajar terutama belajar yang berkaitan dengan keterampilan berbahasa. Sedangkan sebaliknya kecerdasan bahasa dan sikap yang rendah membuat siswa tidak mampu mengendalikan sikap dan malas sehingga mereka akan mengalami kesulitan dalam proses belajar yang tentu saja akan berdampak pada hasil belajar siswa tersebut. Sikap sosial merupakan kesadaran individu untuk bertindak dalam menanggapi atau merespon objek sosial dalam bentuk positif dan negatif. Adapun faktor yang 
mempengaruhi pembentukkan sikap yaitu faktor internal dan faktor eksternal. Faktor internal salah satunya adalah emosi sangat mempengaruhi sikap sosial siswa.

Kecerdasan sikap memegang peranan yang cukup signifikan dalam tutur kata siswa, karena kecerdasan sikap mampu meningkatkan kesadaran diri siswa sehingga siswa dapat lebih mengenali diri sendiri, mengelola emosi, memotivasi diri sendiri, mengenali emosi orang lain, dan membina hubungan baik dengan orang lain dan lingkungan. Selain itu, dalam bertutur kata siswa yang mampu bersikap baik maka akan bertutur kata yang baik pula.

Pembentukan sikap sosial dipengaruhi oleh dua faktor: faktor internal seperti fisologis, emosi, motif dan minat sedangkan faktor eksternal seperti pengalaman, pendidikan dan nilai-nilai norma. Dalam penelitian ini faktor sikap atau Kontribusi variabel $\mathrm{X}$ terhadap variabel $\mathrm{Y}$ dengan $\left(\mathrm{r}^{2} \mathrm{xy} \times 100 \%\right)=0,524^{2} \times 100 \%=0,2745 \times 100 \%$ $=27,45 \%$ maka koefisien determinasinya adalah $27,45 \%$, sehingga hubungan antara kecerdasan bahasa dengan sikap sosial siswa kelas V di SD Negeri Mekarsari II Kabupaten Tangerang besarnya $27,45 \%$ dan $72,55 \%$ lainnya dipengaruhi oleh variable lain Seperti fisologis, motif, minat, pengalamanm pendidikan dan norma-norma nilai. Dengan diperolehnya $t_{\text {hit }}=4,079>t_{\text {tab }}=2,015$ pada taraf signifikan $5 \%$ atau 0,05 maka dapat disimpulkan bahwa terdapat hubungan yang positif dan signifikan antara kecerdasan bahasa (X) dengan sikap sosial siswa (Y) di SD Negeri Mekarsari II Kabupaten Tangerang.

\section{E. Kesimpulan}

Berdasarkan deskripsi data dan analisis data penelitian tentang hubungan antara kecerdasan bahasa dengan sikap sosial siswa kelas V di SD Negeri Mekarsari II kabupaten Tangerang tahun ajaran 2016/2017 pada skripsi ini diambil kesimpulan bahwa terdapat hubungan yang positif dan signifikansi antara kecerdasan bahasa dengan sikap sosial siswa di SD Negeri Mekarsari II Kabupaten Tangerang. Hal ini dapat dilihat dari perhitungan peneliti dengan di perolehnya $t_{\text {hit }} 4,079 \mathrm{t}_{\text {tab }} 2,015$ pada taraf signifikans $5 \%$ atau 0,05 .

Pada pengujian analisis regresi dan korelasi sederhana dengan model regresi $\mathrm{Y}=$ $54,11+0,50 \mathrm{X}$ dan setelah uji coba dengan taraf signifikasi 0,05 ternyata model tersebut 
signifikan dan bentuk hubungannya linear. Sedangkan pada pengujian hipotesis, karena data berdistribusi normal dan pipulasi homogen maka pada perhitungan uji hipotesis menggunakan uji-t diperoleh $\mathrm{t}_{\text {hitung }}=4,079>\mathrm{t}_{\text {tabel }}=2,015$ pada taraf nyata 0,05 , maka dapat disimpulkan bahwa $\mathrm{H}_{\mathrm{o}}$ ditolak dan $\mathrm{H}_{1}$ diterima berarti bahwa korelasi antara $\mathrm{X}$ dan Y signifikan dan terdapat hubungan antara kecerdasan bahasa terhadap sikap sosial siswa kelas V di SD Negeri Mekarsari II Kabupaten Tangerang. Kontribusi kecerdasan bahasa terhadap sikap sosial yang ditunjukan oleh hasil perhitungan dari koefisien determinasi 0,2745. Ini berarti kecerdasan bahasa mempunyai kontribusi sebesar $27,45 \%$ terhadap sikap sosial, dan 72,55\% lainnya dipengaruhi oleh variable lain.

\section{F. Daftar Pustaka}

Ahmadi, A (2007). Psikologi Sosislal. Jakarta: Rineka Cipta.

Arifin, B.S. (2015). Psikologi Sosial. Bandung: CV Pustaka Setia.

Kurniawan, Heru. 2013. Kemahiran Berbahasa Indonesia. Banyumas: Kaldera Press . 2016. Kreatif Mendongeng untuk Kecerdasan Jamak Anak.

Jakarta: Kencana

Uno, H.B. (2016). Orientasi Baru Dalam Psikologi Pembelajaran. Jakarta: PT Bumi Aksara. 